\title{
Giving Reinforcement with 2.0 Framework by Teacher: A Photovoice of Undergraduate Students in the EFL Classroom
}

\author{
Arum Yuliazari*, Aulia Majid, Desy Pusparini, Nur Arifah Drajati \\ Universitas Sebelas Maret \\ Email : arumazari@gmail.com,
}

\begin{abstract}
Reinforcement has been used in many areas of educational institution. In the learning activity, reinforcements are given by the teacher as feedback for what students have done. By using reinforcement in the learning activity, the students are expected to feel comfortable to show themselves by responding questions, giving feedback, and expressing their opinions in the class. This study aims to investigate the effect of giving reinforcement by the teacher towards student's learning motivation. This research used the photovoice method and SHOWeD Analysis. The participants are 27 students in 5th semester of English Education Department in online class, consists of 7 males and 20 females with the average age of around 19-21 years old. The finding shows that giving reinforcement encourage student's motivation in the learning activity. As the implication, teachers apply reinforcement in order to make the students high-motivated in the class.
\end{abstract}

\section{INTRODUCTION}

A success learning process is a process of learning which both teacher and students can build effective learning. Effective learning emphasizes intrinsic motivation, social relationship for learning, and an overall learning culture (Senge, 2000). In order to build students' motivation, the situation of a class should be able to make the students happy to attend the class and comfortable to express their ideas. One of the possible ways to grow students' confidence in expressing their ideas is by giving reinforcement. One thing that makes students happy throughout the educational lives is given reinforcement in the form of appreciation and rewarding (Goksoy, 2017).

However, the real situation is that most of the students worried about how their teacher will respond to them if they want to be involved in the class activities such as answering questions, asking questions, giving a suggestion, and such things. They got anxious to show their capability in the class. This problem frequently happens, especially to them categorized as an introverted person.

Up to this time, the research that investigates the effect of reinforcement on the students' motivation with 2.0 framework, which class held in a media platform, has not existed. The previous researches usually conduct a study in a formal classroom, such as Hill M. Walker and Nancy K. Buckley (1968) and Goksoy (2017). Therefore, the researchers took the opportunity to conduct this research with a different setting, that is with 2.0 framework.

By conducting this research, the researchers want to know:

1. What are the effects of reinforcement given by a teacher towards students' learning motivation?

2. Why is positive feedback important for the student?

Reinforcement is expected to make students feel comfortable with the class atmosphere. This also expected to make them brave to show themselves by 
responding questions, giving feedback, and expressing their opinions in the class. If the situation achieved, the students are quickly getting their motivation to be involved in the learning activity and enhance their grade.

According to B. F. Skinner (1938), Reinforcement theory is the process of shaping behavior by controlling consequences of the behavior. Reinforcement theory proposes that you can change someone's behavior by using reinforcement, punishment, and extinction.

Reinforcement divided into positive reinforcement and negative reinforcement (Skinner, 1938). Positive reinforcement occurs when the consequence is resulting in the behavior you are attempting to produce increases the probability that the desired behavior will continue. If a salesperson performs well, that salesperson may receive a bonus, which reinforces the desire to make sales because of the positive consequence of doing so. Negative reinforcement occurs when a negative consequence is withheld if the behavior you desire is demonstrated, which will increase the probability that the behavior you are seeking will continue

Based on A. H. Maslow (1943), human needs arrange themselves in hierarchies of pro-potency. That is to say, the appearance of one need usually rests on the prior satisfaction of another, more pre-poten need. Man is a perpetually wanting animal. Also, no need or drive is related to the state of satisfaction or dissatisfaction of other drives.

According to Dornyei (1994), we can see that there are three components of motivation, they are specific motivational components of course which include syllabus, teaching materials, teaching methodology and exercises, specific motivational components of teachers which has to do with teachers' personality, teaching style, feedback and relationship with the students, and Specific motivational components of the group which has to do with dynamic teaching group.

\section{METHOD}

This research used photovoice as a tool to analyze the data of a reinforcement effect for students' motivation in an ELT classroom. The definition of photovoice is a participatory action research strategy based on educational theories and health principles to contribute to social issues and community change. (C. Wang \& M.A. Burris, 1997). For researchers, the use of photographs helps to kindle dialogue amongst participants about their perceptions of the issues under discussion; further, different ideas obtained than those gathered solely from interviews or focus groups (Darbyshire, MacDougall, \& Schiller, 2005). It is the combination of the narrative and visual depictions that enhances the ability of researchers to accurately capture the meaning of an issue from the participant's point of view (Harrison, 2002; McIntyre, 2003; Nowell et al., 2006).

The participants of this research are 27 students in 5th semester of English education Department in online Advanced Grammar class, consists of 7 males and 20 females with the average age of around 1921 years old. Researchers used a questionnaire and an interview to collect the data. After the participants given reinforcement from the lecturer, the researchers give the questionnaire and hold an interview. After that, the researchers analyze the results of the questionnaire and the interview by using $\mathrm{SHOWeD}$ analysis.

This photovoice project proposed to understand what happens in the class. In the photovoice project, we used SHOWeD analysis. SHOWeD is the acronyms of several questions in the questionnaire that 
the participants should answer while analyzing pictures.

$S$ - What do you see?

$\mathrm{H}-$ What is really happening here?

$\mathrm{O}$ - How does this relates to our lives?

W- Why does the situation, concern, or strength exist?

e - How could this image educate the community?

D - What can we do about it?

\section{RESULTS AND DISCUSSION}

\subsection{Results}

This research was conducted to investigate whether there is an effect of giving reinforcement by the teacher towards student's learning motivation. The researchers found that giving reinforcement has a positive effect on students' learning motivation. It is proven by the data taken from the interview with the participants.

At first, the teacher asked the students to answer some questions related to the material of Advanced Grammar. After giving instruction, the teacher sent the questions. The students are given time to think about the answer and send it to the group discussion. The teacher gave a chance to any volunteer who wanted to answer the questions first. Many of the students started to answer the questions based on their capability. Then, the teacher gave them feedbacks to them like "Good Job!" and "Yea. Love Ur work!" and gave the explanation about the correct answers and discussed it together with the students.

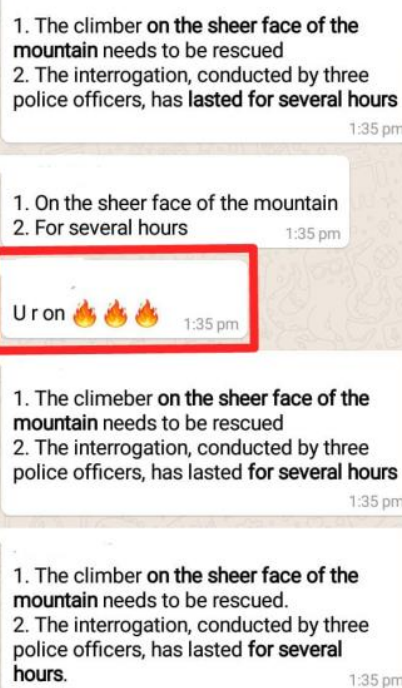

Figure 1. shows that based on SHOWeD analysis of the picture, one of the
S - what do you see here?

Answer: What I see is that lecturer gives a compliment to the students about their work.

$\mathrm{H}$ - what is happening here?

Answer: The lecturer is happy to see the students' work. $\mathrm{O}$ - how does this relates to our lives?

Answer: Sometimes we need to give a compliment to the students so that they can give their best.

W - why this situation exists?

Answer: Because the lecturer is satisfied with the students' work or task.

e - how could this image educate to the community? Answer: By giving such kind of compliment, the students will feel that their work is appreciated.

D - what can we do about it?

Answer: As a teacher or lecturer we should give the compliment to the students so that they will be motivated to improve their skills.

Figure 1. The teacher gave reinforcement in the form of rewarding to the students' spirit when answering questions 
learning which given reinforcement by the teacher. The students felt that their work is appreciated so they will be motivated to improve their skills. "I want to answer because the teacher appreciated my previous work. So I expect the next work has the same treatment so that I will be motivated to answer again and again." It was not the first time she answered the

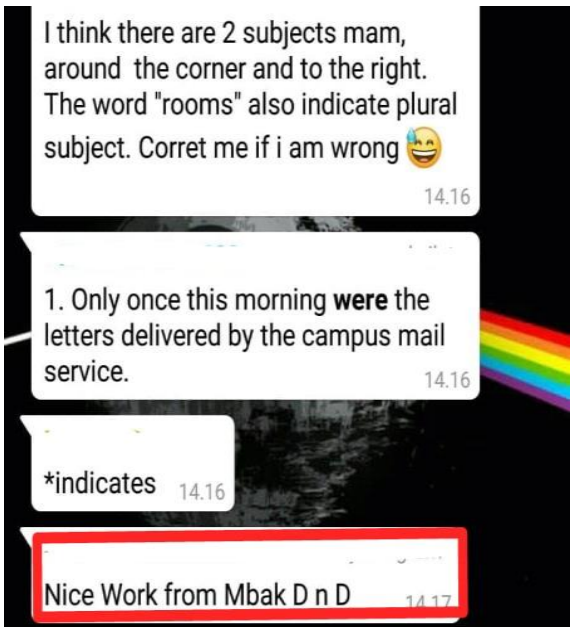

The second participant explained that being given reinforcement from the teacher can make the students free from anxiety and make them brave to answer the question from the teacher. "The point is, by being appreciated by the lecturer, in question from the teacher, in the previous work she had got the similar reinforcement. It shows that reinforcement from the teacher influences and motivates the students to do the instruction later in the next time.

S - what do you see here?

Answer: what I see is the teacher give positive reinforcement.

$\mathrm{H}$ - what is happening here?

Answer: the lecturer shows the right attitude in teaching towards their (students) work.

$\mathrm{O}$ - how does this relates to our lives?

Answer: reinforcement is needed in order to support students' motivation. W - why this situation exists? Answer: because the students are able to answer the questions correctly. e - how could this image educate to the community? Answer: teacher's reinforcement support students' activeness in class. D - what can we do about it?

Answer: the teacher should maintain giving positive reinforcement to the students.

Figure 2. The teacher gave reinforcement in the form of rewarding to the students' spirit when answering questions 


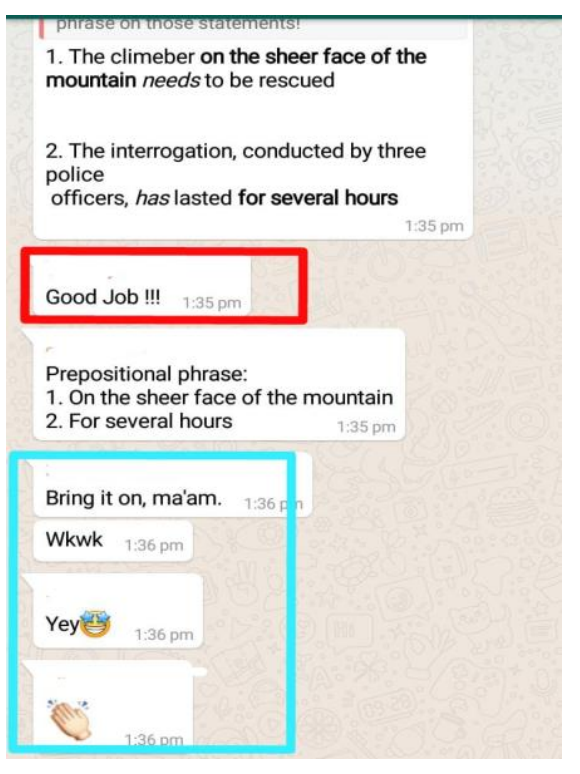

S - what do you see here?

Answer: i see that the student is excited about the online class activity

$\mathrm{H}$ - what is really happening here? Answer: What really happens is that the student asked for more quiz from the teacher $\mathrm{O}$ - how does this relates to our lives? Answer: the student just joking $\mathrm{W}$ - why this situation exists? Answer: this situation exists because of the exciting class activity e - how could this image educate to the community? Answer: this image may educate the community about joking

D - what can we do about it?

Answer: We can imply that it is the representation of class activity enjoyment

Figure 3. The teacher gave reinforcement to what the students had done. A student

Figure 3 shows that the third participant told in the interesting online classroom situation, the students joke with the teacher. He experienced an enjoyment in an exciting online classroom situation. He added the students could laughing and joking with the teacher because the class is exciting and they were getting more excited with the teacher's characters. The participant added "wkwk" (laugh) in the online class which was for the excitement and jokes expression. He said, "I added the wkwk (laugh) expression because of that expression used for the previous joke."

The result of the research above shows that by giving positive feedback to the students' work has an important role. From the SHOWed analysis, we know that teacher can motivate the students to do more and develop their skills inside the class. The students also felt more appreciated in doing the teacher's instruction by receiving positive feedbacks. Positive feedbacks also make the students excited and less anxious inside the class.
This result has a similar effect to the previous study which

concludes that giving reinforcement in the form of appreciation and rewarding makes students happy (Goksoy, 2017). Moreover, students also make a joke with the teacher as a result of the excitement.

According to B. F. Skinner (1938), Reinforcement theory is the process of shaping behavior by controlling consequences of the behavior. Reinforcement theory proposes that you can change someone's behavior by using reinforcement, punishment, and extinction. The research findings show that giving reinforcement can develop the students' learning motivation and have a good chance for the students to show their capability confidently. Reinforcement which is given by the teacher can mentally support the students' brave to answer the questions given because they did not have any anxiety if their answer is wrong. They did not afraid if they will be wrong because they knew the teacher will not blame them 
or interrupt them. One important thing proven, a student who ever got reinforcement from the teacher when answering questions will have a bigger motivation to answer the questions again in the next session or meeting. The student's feeling also becomes more peaceful so they can express it excitedly using many kinds of expression such as "wkwk" (laugh) which is used to show they were laughing.

\section{CONCLUSION}

Based on the research of the study, it concluded that giving reinforcement to student influence students' learning motivation such as the students can express their desire and emotion like being more active after getting reinforcement and making jokes in the class discussion. When they get their motivation, they also can be free from any anxiety when they want to participate the class activities. Comparing with the theory of reinforcement, it was proven that reinforcement change student's behavior. Reinforcement given by teacher can make the students more active and expressive when participating in every activity in the class. Besides, reinforcement makes the class' situation less anxious because the students are very excited and they can give some joke expressions.

\section{REFERENCES}

Darbyshire, P., MacDougall, C. and Schiller, W. (2005) Multiple Methods in Qualitative Research with Children: More Insight or Just More?. Qualitative Research, 5, 417436.

Dornyei, Z. (1994). Motivation and Motivating in Language Foreign Classroom. The Modern Language Journal, pp. 273-284

Edwin, C. (1995) .Understanding Organizations as Learning Systems. Gould Sloan Management Review, pp. 73-85
Goksoy, Asli (2017). The Role of Psychological Empowerment and Organizational Citizenship Behaviors on Employee Resistance to Change. European Journal of Interdisciplinary Studies, [S.l.], v. 3, n. 2, p. 85-93.

Harrison, B. (2002). Photographic visions and narrative inquiry. Narrative Inquiry, 12(1), pp. 87-111

HM Walker, NK Buckley (1968). The Use of Positive Reinforcement in Conditioning Attending Behavior. Journal of Applied Behavior Analysis. p. 245-250

Maslow, A. H. (1943). A theory of human motivation. Psychological Review, 50(4), 370-396.

Mcintyre, A. (2010). Through the Eyes of Women: Photovoice and participatory research as tools for reimagining place. A journal of Feminist Geography, 10(1), 47-66.

Nykiforuk, C., (2011). Photovoice as a Method for Revealing Community Perceptions of the Built and Social Environment. International Journal of Qualitative Method, 10(2), 103124.

Wang, C., \& Burris, M. A. (1997). Photovoice: concept, methodology, and use for participatory needs assessment. Health education \& behavior, 24(3), 369-387

Williams, S. B. (1938). Resistance to extinction as a function of the number of reinforcements. Journal of Experimental Psychology, 23(5), 506-522. 